\title{
Topicality of the problem of combined course of multi-drug resistant pulmonary tuberculosis with diabetes mellitus
}

\author{
0. M. Raznatovska ${ }^{1}$, Yu. M. Bobrovnycha-Dvizova ${ }^{1}$, S. B. Norejko ${ }^{2}$, N. A. Gricova ${ }^{3}$ \\ ${ }^{1}$ Zaporizhzhia State Medical University, Ukraine, ${ }^{2}$ Bogomolets National Medical University, Kyiv, Ukraine, \\ ${ }^{3}$ Shupik National Medical Academy of Postgraduate Education, Kyiv, Ukraine
}

Key words: multidrug-resistant tuberculosis, pulmonary tuberculosis, diabetes mellitus.

Pathologia 2017; 14 (2), 236-240

DOI:

10.14739/2310-1237.

2017.2.109676

E-mail:

raxnatovskaya@ gmail.com
According to the World Health Organization, today in the world among the infectious chronic diseases one of the leading places and causes of death is multi-drug resistant tuberculosis of the lungs, and chronic non-communicable diseases - diabetes mellitus. The situation is complicated by the fact that the number of patients with combined course of these two heavy separate illnesses that complicate each other increases. It is established that with increasing severity of diabetes mellitus, tuberculosis process in the lungs becomes more complicate and deteriorates, and vice versa, the specific process complicates the course of diabetes mellitus, contributing to the development of diabetic complications. Against this background, the effectiveness of treatment of patients suffering from multi-drug resistant tuberculosis of the lungs in our country remains very low, mainly due to the toxic adverse reactions to antimycobacterial drugs of the reserve line, and in the case of adding diabetes mellitus, it deteriorates even more.

The aim of this study was to review the scientific literature to determine the relevance of the study of combined course of multidrug resistant tuberculosis of the lungs with diabetes mellitus and perspectives of innovative methods of diagnosis of diabetes mellitus. Early diagnosis of pre-diabetes, and autoimmune diseases will allow the use of timely correction techniques that prevents the development of diabetes mellitus, depending on its type, and in the future the development of serious irreversible processes, allow timely applying appropriate methods of correction of the revealed violations.

Results. Very little amount of work is dedicated to the problem of combined course of multi-drug resistant tuberculosis of the lungs with diabetes mellitus, regardless of its type, the theme is relevant for today, in Ukraine there are no data regarding its study. This combined course of very difficult in the treatment diseases requires not only timely and early diagnosis of autoimmune diseases associated with diabetes mellitus type 1 and pre-diabetes, but also additional complex combined therapy.
Кмючові слова: мультирезистентний туберкульоз мегень, цукровий діабет.

Патологія. - 2017. -

T. 14, № 2(40). -

C. 236-240

\section{Актуальність проблеми поєднаного перебігу мультирезистентного туберкульозу легень із цукровим діабетом}

\section{О. М. Разнатовська, Ю. М. Бобровнича-Авізова, С. Б. Норейко, Н. А. Гріцова}

За даними Всесвітньої організації охорони здоров'я (ВООЗ), сьогодні в усьому світі серед інфекційних хронічних захворювань одне з провідних місць і причин смерті посідає мультирезистентний туберкульоз легень, а неінфекційних хронічних захворювань - цукровий діабет. Ситуація ускладнюється тим, що збільшується кількість пацієнтів із поєднаним перебігом цих двох тяжких поокремо захворювань, які ускладнюють одне одного. Так, встановлено, що під час збільшення ступеня тяжкості цукрового діабету ускладнюється та стає важчим перебіг туберкульозного процесу в легенях, i, навпаки, специфічний процес ускладнює перебіг цукрового діабету, сприяючи розвитку діабетичних ускладнень. На цьому тлі ефрективність лікування хворих на мультирезистентний туберкульоз легень у нашій країні залишається дуже низькою, переважно внаслідок токсичних побічних реакцій на антимікобактеріальні препарати резервного ряду, а при приєднанні ще й цукрового діабету вона значуще погіршується.

Мета роботи - огляд наукової літератури щодо встановлення актуальності вивчення поєднаного перебігу мультирезистентного туберкульозу легень із цукровим діабетом і перспектив інноваційних методів діагностики цукрового діабету. Встановлено, що рання діагностика предіабету й аутоімунних захворювань дасть можливість застосувати своєчасні методи корекції, що запобігатиме розвитку цукрового діабету залежно від його типу, а надалі - тяжких незворотних процесів, своєчасно застосувати відповідні методи корекції виявлених порушень.

Висновки. Проблемі поєднаного перебігу мультирезистентного туберкульозу легень із цукровим діабетом (незалежно від його типу) присвячено дуже мало робіт, тому тема є актуальною сьогодні, а в Україні відсутні дані щодо її вивчення. Такий поєднаний перебіг дуже складних у лікуванні захворювань потребує не тільки своєчасної та ранньої діагностики аутоімунних захворювань, що асоційовані з цукровим діабетом 1 типу, та предіабету, але й додаткової складної комплексної терапії.

\section{Ключевые слова: мультирезистент- ный туберкулёз лёгких, сахарный Аиабет. \\ Патология. - 2017. - T. 14, № 2(40). - \\ C. $236-240$}

\section{Актуальность проблемы сочетанного течения мультирезистентного туберкулёза лёгких с сахарным диабетом}

\section{Е. Н. Разнатовская, Ю. М. Бобровнича-Авизова, С. Б. Норейко, Н. А. Грицова}

По данным Всемирной организации здравоохранения (ВО3), сегодня во всём мире среди инфекционных хронических заболеваний одно из ведущих мест и причин смерти занимает мультирезистентный туберкулёз легких, а неинфекционных хронических заболеваний - сахарный диабет. Ситуация осложняется тем, что увеличивается количество пациентов с сочетанным течением этих двух тяжёлых по отдельности заболеваний, которые усложняют друг друга. Так, установлено, 
что при увеличении степени тяжести сахарного диабета осложняется и утяжеляется течение туберкулёзного процесса в лёгких, и, наоборот, специфический процесс осложняет течение сахарного диабета, способствуя развитию диабетических осложнений. На этом фоне эффективность лечения больных мультирезистентным туберкулёзом лёгких в нашей стране остаётся очень низкой, преимущественно за счёт токсических побочных реакций на антимикобактериальные препараты резервного ряда, а при присоединении ещё и сахарного диабета она значительно ухудшается.

Цель работы - обзор научной литературы на предмет установления актуальности изучения сочетанного течения мультирезистентного туберкулёза лёгких с сахарным диабетом и перспектив инновационных методов диагностики сахарного диабета. Установлено, что ранняя диагностика предиабета и аутоиммунных заболеваний позволит применить своевременные методы коррекции, предупредить развитие сахарного диабета в зависимости от его типа и в дальнейшем - тяжёлых необратимых процессов, своевременно применить соответствующие методы коррекции выявленных нарушений.

Выводы. Проблеме сочетанного течения мультирезистентного туберкулёза лёгких с сахарным диабетом независимо от его типа посвящено очень мало работ, тема на сегодня актуальная, а в Украине отсутствуют данные о её изучении. Такое сочетанное течение очень сложных в лечении заболеваний требует не только своевременной и ранней диагностики аутоиммунных заболеваний, ассоциированных с сахарным диабетом 1 типа, и предиабета, но и дополнительной сложной комплексной терапии.

According to the World Health Organization (WHO), today in the world among the infectious chronic diseases one of the leading places and causes of death is multi-drug resistant tuberculosis (MDRTB) of the lungs, and chronic non-communicable diseases - diabetes mellitus (DM) $[22,23]$. The situation is complicated by the fact that the number of patients with combined course of these two heavy separate illnesses that complicate each other increases. It is established that with increasing severity of diabetes mellitus, tuberculosis process in the lungs becomes more complicate and deteriorates, and vice versa, the specific process complicates the course of diabetes mellitus, contributing to the development of diabetic complications [1-3]. Against this background, the effectiveness of treatment of patients suffering from MDRTB of the lungs in our country remains very low, mainly due to the toxic adverse reactions to antimycobacterial drugs of the reserve line, and in the case of adding diabetes mellitus, it deteriorates even more.

Therefore, the aim of this study was to review the scientific literature to determine the relevance of the study of combined course of MDRTB of the lungs with DM and perspectives of innovative methods of diagnosis of DM.

DM is a group of metabolic diseases characterized by hyperglycaemia which is a consequence of defects in insulin secretion, its action or both these factors $[4,5]$. DM type 1 is insulin dependent disease developing primarily in childhood and characterized by hyperglycaemia, if it is left untreated, and subsequent high risk are vascular disorders usually developing over decades. DM type 2 is a disease predominantly of slow start, mainly found in adults and associated with signs of metabolic syndrome. It has a very high risk of vascular diseases. Although it is not insulin dependent, many patients with this condition will eventually require insulin therapy to control optimal blood glucose level.

In patients suffering from DM tuberculosis is diagnosed 5 times more often in persons of young working age than in general among the population. Therefore, the DM is referred to the group of risk on tuberculosis disease [6].

At the preliminary analysis of the literature, we found out that in case of tuberculosis of the lungs with retained sensitivity of mycobacteria of tuberculosis (MBT), the characteristics of diabetes depending on type, are [1]:

1. For DM type 1: at mild and medium-severe course limited forms of the specific process without degradation, and for heavy one-common clinical forms with a expressed exudative component and the rapid development of caseous (tyroid) necrosis.

2. DM type 2 develops mainly in patients with recurrent tuberculosis cases and is characterized by asymptomatic course and slow progression.

In the literature it was found only a few scientific works devoted to studying features of state and effectiveness of treatment of MDRT of the lungs, including with extended MBT resistance (ERTB), in patients with different types of DM. Thus, O. G. Komissarova et al. $(2013,2015)[7,8]$ found out that in patients with DM type 1, MDRTB of the lungs develops in $5-10$ years and is characterized by severe tuberculous intoxication, a common specific destructive $(100 \%)$ infiltrative process in the lungs with the prevalence of cavities up to $2 \mathrm{~cm}$ in diameter. In this case the patients were mostly aged from 19 to 29 years. In patients with DM type 2, on the contrary, MRTB of the lungs develops mainly in the first 4 years after the diagnosis of DM, the patients are primarily older than 50 years, and the specific process in the lungs is characterized by a predominance of fibro-cavernous forms with cavities of more than $4 \mathrm{~cm}$ in diameter on the background of moderately expressed tuberculous intoxication. In the patients with both types of DM in the early antimycobacterial treatment, decompensation of carbohydrate metabolism is defined, correction of which was held with insular therapy in both groups. The authors additionally used also a variety of pathogenic agents (angioprotectors, heparin and drugs to eliminate side reactions due to the action of antimycobacterial therapy), symptomatic treatment, plasmapheresis, laser- and collapsotherapy. However, against such a massive complex treatment, the authors determine that the effectiveness of therapy in terms of cessation of bacterial excretion was not significantly different depending on the type of DM and accounted for 67-75\%, and according to the healing time, degradation was significantly faster for 1 month in patients with combined course of DM type 1, due to the young age of patients and the nature of the specific process in the lungs.

Thus, in the case of pulmonary tuberculosis with preserved sensitivity, a concomitant DM type 1 has an aggressive character, and DM type 2 has more favourable course due to the following factors. According to the aetiology of the classification of DM by WHO [21], DM type 1 is characterized by the destruction of $\beta$-cells leading to absolute insulin deficiency, and DM type 2 - from predominant insulin resistance with relative insulin deficiency to pre- 
dominant secretory defect with insulin resistance or without it. It means that on the basis of DM type 2 there is insulin resistance on the background of preserved ability of $\beta$-cells to secrete insulin. After all, the complex treatment of patients with combined course of MDRTB of the lungs and DM, which includes the correction of carbohydrate metabolism and diversity of additional pathogenetic and symptomatic drugs against the background of antimycobacterial therapy is more effective in the case of combination with DM type 1 , despite its aggressiveness.

As it is known, insulin is a major regulator of carbohydrate, lipid and protein metabolisms in the body. With insufficient insulin, glycogenolysis stimulates in the liver, thereby hyperglycemia develops. The latter, in turn, causes glycosylation of proteins and lipids with the formation of end products.

According to V. N. Titov and Yu. K. Shyryaeva (2011) [9], one of the negative consequences of hyperglycemia is the development of systemic inflammatory response syndrome of the organism, which is strongly marked in patients suffering from pulmonary tuberculosis even without concomitant DM.

After the review of the scientific literature on pathophysiological factors of the adverse effects of DM on the course of pulmonary tuberculosis, O. G. Kaminskaya and R. Yu. Abdullayev (2014) [10] in their scientific article concluded that today established relevance of hyperglycaemia in the development of $\mathrm{DM}$ is unquestionable, as it facilitates the launch of a number of the adverse pathophysiological mechanisms which are interrelated and exacerbate each other - it is called oxidative stress, chronic vasculitis, progressive atherogenesis, angiopathy, hypercoagulability syndrome. The majority of these mechanisms are associated with pulmonary tuberculosis.

Today the importance of the definition of prediabetes which involves disorders of carbohydrate metabolism: impaired glucose tolerance (per-oral glucose tolerance test (2 hours after taking $75 \mathrm{~g}$ of glucose) $\geq 7.8 \mathrm{mmol} / \mathrm{l}$ ), impaired fasting glycemia (level of glucose in plasma of venous blood $\geq 6.1 \mathrm{mmol} / \mathrm{l}$ and $<7 \mathrm{mmol} / \mathrm{l})[4,11]$.

Insulin resistance is one of the links in the genesis of disorders of glucose tolerance and is determined by the disruption of normal transmission of insulin on insulin-dependent cells [10]. It has been proven and substantiated that insulin resistance against the normal insulin level together with periodic hyperglycaemia are factors of stimulation of $\beta$-cell function insular apparatus of the pancreas and its depletion [12]

Therefore, the deterioration of insulin secretion and insulin resistance are the trigger mechanisms for the development of DM type 2 and pre-diabetes is the initial stage of it.

T. V. Smurova and S. I. Kovaliova (2007) [13] indicate that violations of all types of metabolism in patients suffering from DM type 2 lead to the accumulation of a large number of substances which stimulate the development of MBT. Ketosis is a cause of infringement of oxidative processes in the body, disruption of phagocytic activity of alveolar macrophages, inhibition of phagocytosis, etc.

It was established experimentally that the progression of tuberculosis correlates with a decrease in the mass of the pancreas and the number of $\beta$-cells in its insular apparatus and specific process without DM is accompanied by hyperinsulinemia [10].
Thus, the infectious process in the insolvency of the insular apparatus can provoke disturbance of carbohydrate metabolism, and the more widespread is the infection, the greater are insulin requirements [1]. Therefore, in the case of specific endogenous intoxication in patients with pulmonary tuberculosis, increased need for insulin is one of the first diagnostic signs of the presence of DM.

Combined course of tuberculosis and DM causes profound disruptions of the immune system by stimulating humoral immunity which is the cause of progression of the specific process [13].

G. G. Bayburina (2011) [14] conducted a study of immunological markers of DM in patients on newly diagnosed DM, depending on its type: antibodies to insulin and proinsulin (IAA-insulin autoantibodies, AB-IAA), antibodies to glutamate decarboxylase (GAD-glutamic acid decarboxylase autoantibodies, AB-GAD), antibodies to cytoplasmic antigen of $\beta$-cells (ICA-islet-cell antibodies, AB-ICA). These studies were carried out to establish their association with clinical symptoms, indicators of functional activity of $\beta$-cells of the pancreas (level of basal C-peptide and fasting insulin) and indicators of lipid profile (total cholesterol, a-cholesterol, triglycerides, calculation of atherogenic coefficient). The researcher found out that among patients with DM type 1, immunopositive were $93.8 \%$ of patients aged to 30 years and $68.6 \%$ - in the age category of $31-50$ years. The most significant and reliable indicators among the immunological markers were high titres of $A B-G A D$ and $A B-I C A$. Thus, against the background of expressed clinical picture of $D M$, increasing of titre of immunological markers and decreasing in the level of basal C-peptide, indicators of lipid spectrum and body mass index remained in the normal range. DM type 2 was characterized by the following: immunopositive were $47.5 \%$ of patients (due to the growth of titres $A B-I A A$ and $A B-G A D$ ) against the background of normal values of indicators of the functional activity of $\beta$-cell of the pancreas and elevated levels of the lipid spectrum (total cholesterol and triglycerides). A direct correlation between all indicators of immunological markers with atherogenic coefficient was established; it allowed making conclusion about the dependence of immunological disorders with a state of fat metabolism. For DM type 2 a characteristic feature is the tendency to develop cardiovascular complications.

Thus, diabetes without concomitant TB, depending on the type of the following is true. For type 1: marked clinical manifestations associated with a predominant increase in titres of at-GAD and al-ISA and the decrease in the level of basal C-peptide. For type 2 - the growth of credits at IAA and at-GAD, levels of the lipid spectrum (total cholesterol and triglycerides) and body mass index between which there is a direct correlation, the tendency to develop cardiovascular complications. However, in literature any works have found on similar studies in the case of co-morbid course of MDRTB of the lungs and DM.

The analysis of literary sources showed that researches all around the world regarding the diagnosis and treatment of DM with different types do not tread water. In 2011 innovations in the diagnosis of MD was the fact that WHO adopted the diagnostic levels of glycosylated (glycated) hemoglobin $(\mathrm{Hb})$ to arrive at diagnosis of DM. Thus, the level of $\mathrm{HbA} 1 \mathrm{c}$ $<5.7 \%$ is a norm, at its level between $5.7-6.4 \%$ - the risk of developing DM and > at its level $>6.5 \%$ - they arrive 
to diagnosis of DM $[15,22]$. This approach allows not only the early diagnose of diabetes, but also to promptly apply preventive measures in high-risk groups, preventing the development of this severe disease.

In levels of glycosylated $\mathrm{Hb}$, blood glucose and glycosuria there are three levels of violation of carbohydrate metabolism [15,23]:

1. Compensated: the level of glycosylated $\mathrm{Hb}$ from 6 to $7 \%$, fasting glucose up to $6 \mathrm{mmol} / \mathrm{l}$ and after meals up to $8 \mathrm{mmol} / \mathrm{l}$ in the absence of glycosuria.

2. Sub-compensated: the level of glycosylated $\mathrm{Hb}$ from 7.1 to $7.5 \%$, fasting glucose from 6.1 to $6.5 \mathrm{mmol} / \mathrm{l}$ and after meals from 8.1 to $9 \mathrm{mmol} / \mathrm{l}$, glycosuria $(+)$.

3. Decompensated: the level of glycosylated $\mathrm{Hb}$ above $7.5 \%$, fasting glucose above $6.5 \mathrm{mmol} / \mathrm{l}$ and after meals above $9 \mathrm{mmol} / /$, glycosuria (+++).

Molecular genetic methods of diagnostics allow timely and quickly detecting different variants of DM that require different kinds of treatment. Thus, V. E. Tytovych et al. (2010) [16] as a result of 11 years of research of contributory and protective gal types (HLA-DRB1, DQ genes) in combination with immunological markers $(A B-I C A, A B-$ IAA and $A B-G A D$ ) found the risk of developing DM type 1 which suggests that the presence in healthy sibs $D Q-2$, DQ-8 of gal types predicts a high risk of its development. And among those who have already got sick with DM type 1 in the initial stages, a high titre of all immunological markers revealed. Therefore, the researchers came to the following conclusion that the assessment of the risk of developing DM type 1 on the basis of molecular-genetic and monitoring of immunological markers is a stage in the development of preventive measures aimed at prevention of the development of the disease.

Today it is found out that one-third of cases of DM type 1 is accompanied by other endocrine and not endocrine autoimmune diseases that influence the degree of its compensation [17]. It is established that on the basis of most autoimmune diseases is the violation of T-cell immunity, which leads to destruction of tissue, atrophy of the organ and reduction of hormone production. The leading place among these diseases is autoimmune thyroiditis (up to $30 \%$ of cases), followed by frequency of development by autoimmune gastritis and/or pernicious anaemia (up to $10 \%$ of cases) [24] and autoimmune hepatitis [18]. Therefore, for early diagnosis of these concomitant autoimmune diseases, the change of which precedes the development of clinical signs, the study of AT is relevant: at autoimmune thyroiditis to thyroperoxide (TPO) and receptor of thyrotropic hormone ( $\mathrm{rTTH})$, autoimmune gastritis $-A B$ to parietal cells of the stomach (PCS), autoimmune hepatitis - anti smooth muscle $A B$ (ASMA) and antinuclear AB (ANA).

Today it is found that one-third of cases of type 1 diabetes is accompanied by other endocrine and not endocrine autoimmune diseases that influence the degree of compensation [17]. It is established that at the root of most autoimmune diseases is the violation of T-cell immunity, which leads to destruction of tissue, atrophy of the organ and reduction of hormone production. The leading place among these diseases is autoimmune thyroiditis (up to $30 \%$ of cases), followed by frequency of development are autoimmune gastritis and/or pernicious anaemia (up to $10 \%$ of cases) [24] and autoimmune hepatitis [18]. Therefore, for early diagnosis of these concomitant autoimmune diseases, which change precedes the development of clinical manifestations relevant is the study of AO: autoimmune treaded to triperoxide (TPO) receptor and thyrotropic hormone (rTTH), autoimmune gastritis - antibody to parietal cells of the stomach (PCA), autoimmune hepatitis - antipodal Azov AO (AGMA) and at antinuclear (ANA).

It was found out that patients in the initial stages of DM type 1 with the growth of titre AB-GAD, AB TPO are detected [17], while the function of the thyroid gland is not violated. M. Prazny et al. (2005) [25] indicate that excess production of thyroid hormones leads to impairment of glucose uptake and acceleration of gluconeogenesis and glycogenolysis in the liver, and this leads to the development of insulin resistance. K. Vondra et al. (2005) [26] found out that hyperthyreosis in patients with DM type 1 is a cause for the development of ketoacidosis.

V. V. Fadeyev et al. (2006) [19] conducted studies and recommend using determination of the level of the titre rTTH by the method of radio-receptor assay in clinical practice for the diagnosis of autoimmune thyroiditis.

In the literature some works were found devoted to the study of thyroid pathology in patients with pulmonary tuberculosis in Ukraine. Thus, S. L. Matveyeva (2017) [20] in order to diagnose autoimmune thyroiditis was studying the levels of free thyroxin (v. T4), AB rTTH, AB to thyroglobulin (AB TG) and AB TPO. According to the data obtained she established that in patients suffering from pulmonary tuberculosis with concomitant DM in $66.67 \%$ of cases autoimmune thyroiditis with symptoms of subclinical hypothyroidism is diagnosed, which negatively affects both the clinical course of tuberculosis, and the result of antimycobacterial treatment.

Thus, early diagnosis of pre-diabetes, and autoimmune diseases will allow the use of timely correction techniques that prevents the development of DM, depending on its type, and in the future the development of serious irreversible processes, allow timely applying appropriate methods of correction of the revealed violations.

\section{Conclusions}

1. Very little amount of work is dedicated to the problem of combined course of MDRTB of the lungs with DM, regardless of its type, the theme is relevant for today, in Ukraine there are no data regarding its study.

2. This combined course of very difficult in the treatment diseases requires not only timely and early diagnosis of autoimmune diseases associated with DM type 1 and pre-diabetes, but also additional complex combined therapy.

Prospects for further scientific researches. Further study of pathophysiological, biochemical and immunological disorders in the case of co-morbid course of MDRTB of the lungs with DM, improving the corrective therapy, the development of ways to prevent the development of DM in patients suffering from MDRTB of the lungs with the presence of risk factors, etc.

\section{References}

[1] Shalmin, A. S., Raznatovskaya, E. N., Bobrovnichaya-Dvizova, Yu. M., Dvizov, A. V., Mulyar, N. V., \& Fedchenko, T. S. (2012). Osobennosti sochetannogo techeniya tuberkuleza legkikh i sakharnogo diabeta [Features of the combined $\mathrm{fl}$ ow of pulmonary tuberculosis and diabetes mellitus]. Pathologia, 1(24). 92-94. [in Russian]. 
[2] Komissarova, O. G. (2012). Tuberkulez u bol'nykh sakharnym diabetom. [Tuberculosis in patients with diabetes mellitus]. Tuberkulez $i$ bolezni legkikh, 11, 3-7. [in Russian].

[3] Papenova, E. L., Odinec, V. S., Zadremailova, T. A., Vasilenko, T. I., \& Akinina, S. A. (2015). Vliyanie rannego vyyavleniya tuberkuleza organov dykhaniya u bol'nykh sakharnym diabetom na e'ffektivnost' lecheniya v Stavropol'skom krae [Influence of Early Detection of Respiratory Tuberculosis in Patients with Diabetes Mellitus on the Effectiveness of Treatment in the Stavropol Territory]. Tuberkulez i bolezni legkikh, 7 , 109-110. [in Russian].

[4] Ministerstvo okhorony zdorov'ia Ukrainy (2012). Unifikovanyi klinichnyi protokol pervynnoi ta vtorynnoi (spetsializovanoi) medychnoi dopomohy. Tsukrovyi diabet 2 typu [Unified clinical protocol of primary and secondary (specialized) medical care. Type 2 diabetes mellitus]. Kyiv [in Ukrainian]

[5] Dedov, I. I. (2012). Sakharnyj diabet - opasnejshij vyzov mirovomu sosobshhestvu. [Diabetes mellitus - a dangerous treat to the mankind]. Vestnik Rossijskoj akademii medicinskih nauk, 67(1), 7-13. [in Russian]. doi :10.15690/vramn.v67i1.103.

[6] Sirenko, I. A., Levchenko, E. A., Sukhanova, L. A., \& Marchenko, O. Yu. (2016). Problema tuberkuleza i saKharnogo diabeta [Tuberculosis and diabetes problem]. Tuberkuloz, lehenevi khvoroby, VIL-infektsiia, 4(27), 54-59. [in Ukrainian].

[7] Komissarova, O. G., Kossij, Yu. E., Abdullaev, R. Yu., Moiseeva, S. V., \& Vasilyeva, I. A. (2013). Osobennosti techeniya i e'ffektivnost' lecheniya tuberkuleza legkikh s mnozhestvennoj lekarstvennoj ustojchivost'yu vozbuditelya u bol'nykh s raznymi tipami sakharnogo diabeta [Features of the course and efficacy of treatment of pulmonary tuberculosis with multiple drug-resistant pathogens in patients with different types of diabetes mellitus]. Tuberkuljoz i bolezni legkikh, 90(3), 010-014. [in Russian]

[8] Komissarova, O. G., Konyayeva, O. O., Berezhnaya, O. O., Abdullayev, R. Yu., \& Vasilyeva, I. A. (2015). E'ffektivnost' lecheniya bol'nykh tuberkulezom legkikh s mnozhestvennoj i shirokoj lekarstvennoj ustojchivost'yu vozbuditelya v sochetanii s raznymi tipami sakharnogo diabeta [Efficacy of Treatment of Patients with Multiple and Extensively Drug-Resistant Pulmonary Tuberculosis Combined with Different Types of Diabetes Mellitus]. Vestnik Rossijskogo gosudarstvennogo medicinskogo universiteta, 3, 33-37. [in Russian].

[9] Titov, V. N., \& Shiryaeva, Yu. K. (2011). Glyukoza, glikotoksiny i produkty glikirovaniya, uchastie v patogeneze mikroangiopatiej, arterioloskleroza ateroskleroza [Gyukose, glycotoxins and glycation products, participation in pathogenesis by microangiopathy, arteriolosclerosis and atherosclerosis]. Klinicheskaya laboratornaya diagnostika, 11, 3-13. [in Russian]

[10] Kaminskaya, G. O., \& Abdullaev, R. Y. (2014). Patofiziologicheskie predposylki neblagopriyatnogo vliyaniya sakharnogo diabeta na techenie tuberkuleza legkikh. [Pathophysiological prerequisites for the negative impact of diabetes mellitus on the course of pulmonary tuberculosis] Tuberkuljoz i bolezni legkikh, 9(3), 5-11. [in Russian]. doi: http://dx.doi. org/10.21292/2075-1230-2014-0-3-5-11.

[11] Kaminskii, A. V. (2012). Sakharnyj diabet. Chast' 1. Neprostye voprosy diagnostiki. [Sugar dyabet Part 1. Neprostbe Questions diagnosis] Mezhdunarodnyj e'ndokrinologicheskij zhurnal, 3(43), 43-47. [in Russian].

[12] Glinkina, I. V. (2012). Svoevremennoe nachalo insulinoterapii pri sakharnom diabete tipa 2: patogeneticheskoe i klinicheskoe obosnovanie [Timely initiation of insulin therapy for type 2 diabetes mellitus: pathogenetic and clinical justification]. Consilium medicum, 14(12), 10-15. [in Russian]

[13] Smurova, T. V., \& Kovaleva, S. I. (2007). Tuberkulez i sakharnyj diabet. [Tuberculosis and diabetes mellitus]. Moscow: Medkniga. [in Russian]

[14] Baiburina, G. G. (2011). Immunologicheskie markery sakharnogo diabeta pri razlichnykh klinicheskikh tipakh zabolevaniya [Immunological markers of diabetes mellitus in various clinical variants of the disorder] Medicinskaya immunologiya, 13(6), 623-626. [in Russian]. doi: http:// dx.doi.org/10.15789/1563-0625-2011-6-623-626.

[15] Dedov, I. I., Balabolkin, M. I., Klebanova, E. M., Kreminskaya, V. M., \& Chazova, T. E. (2003). Sakharnyj diabet: patogenez, klassifikaciya, diagnostika i lechenie [Diabetes mellitus: pathogenesis, classification, diagnosis and treatment]. Moscow. [in Russian].

[16] Titovich, E. V., Kuraeva,T. L., Prokofiev, S. A., Peterkova, V. A., \& Dedov, I. I. (2010). HLA-galotipy, autoantitela k $\beta$-kletkam: rol' v prognozirovanii sakharnogo diabeta 1 tipa (rezul'taty 11-letnego nablyudeniya) [HLA-haplotypes, anti- $\beta$ cell antibodies:their role in prognostication oftype 1 diabetes mellitus (results of 11-year observation)]. Sakharnyj diabet, 13(4) 12-17. [in Russian]. doi: http://dx.doi.org/10.14341/2072-0351-6051.

[17] Larina, A. A., \& Troshina, E. A. (2013). Autoimmunnye zabolevaniya, as sociirovannye s sakharnym diabetom 1-go tipa: vozmozhnoe vzaimovliyanie [Autoimmune diseases associated with type 1 diabetes mellitus: possible interplay]. Problemy e'ndokrinologii, 59(1), 35-43. [in Russian].

[18] Derevyanko, O. S., Dalantaeva, N. S., Ivanova, O. N., Goncharov, N. P. Nikonova, T. V., \& Smirnova, O. M. (2014). Markery autoimmunnogo porazheniya pecheni u pacientov s sakharnym diabetom 1 tipa [Markers for hepatic autoimmune disorders in patients with type 1 diabetes mellitus] Sakharnyj diabet, 1, 29-33. [in Russian]. doi: 10.14341/DM2014129-33.

[19] Fadeyev, V., Abramova, N., Gitel, E., Pauncovic, N., Pauncovic, J. Prokofyev, S., \& Melnichenko, G. (2006). Diagnosticheskoe znachenie opredeleniya urovnya antitel $\mathrm{k}$ receptoru tireotropnogo gormona metodami 1-go i 2-go pokolenij [Diagnostic Value of the First and Second Generation of Thyrotropin Receptor Antibodies in Clinical Practice]. Klinicheskaya e'ksperimental'naya tireoidologiya, 2(2), 48-55. [in Russian].

[20] Matveyeva, S. L. (2017). Vliyanie strukturno-funkcional'nykh izmeneni] shhitovidnoj zhelezy na klinicheskoe techenie tuberkuleza i iskhody khimioterapii pri soputstvuyushhem sakharnom diabete [The effect of structural and functional changes in the thyroid gland on the clinica course of tuberculosis and the outcome of chemotherapy with concomitant diabetes mellitus]. Tuberkuloz, lehenevi khvoroby, VIL-infektsiia, 1(28), 54-59. [in Russian]

[21] WHO. (2015). Global Tuberculosis Report 2015 Retrieved from http:// apps.who.int/iris/bitstream/10665/191102/1/9789241565059 eng.pdf.

[22] World Health Organization. (2011). Use of glycated hemoglobin (HbA1c) in the diagnosis of diabetes mellitus. Abbreviated report of a WHO consultation. World Health Organization (WHO/NMH/ CHP/CPM/11.1).

[23] World Health Organization (1999). Definition, Diagnosis and Classification of Diabetes Mellitus and its Complications Report of a WHO Consultation. Part 1: Diagnosis and Classification of Diabetes Mellitus. Department of Noncommunicable Disease Surveillance, Geneva.

[24] Van den Driessche, A., Eenkhoorn, V., Gaal, L., \& Block, C. (2009). Type 1 diabetes and autoimmune polyglandular syndrome: a clinical review. Netherlands J Med, 67(11), 376-387.

[25] Prázný, M., Skrha, J., Límanová, Z., Vanícková, Z., Hilgertová, J., Prázná J., etal. (2005). Screening for Associated Autoimmunity in Type 1 Diabetes Mellitus With Respect To Diabetes Control. Physiol Res, 54, 41-48.

[26] Vondra, K., Vrbikova, J., \& Dvorakova, K. (2005). Thyroid gland diseases in adult patients with diabetes mellitus. Minerva Endocrinol, 30(4), 217-236.

\section{Information about authors:}

Raznatovska O. M., MD, PhD, DSc, Associate Professor, Professor of the Department of Phthisiology and Pulmonology, Zaporizhzhia State Medical University, Ukraine.

Bobrovnycha-Dvizova Yu. M., Assistant of the Department of Phthisiology and Pulmonology, Zaporizhzhia State Medical University, Ukraine.

Norejko S. B., MD, PhD, DSc, Associate Professor, Professor of the Department of Phthisiology and Pulmonology, Bogomolets National Medical University, Kyiv, Ukraine.

Gricova N. A., MD, PhD, Associate Professor of the Department of Phthisiology and Pulmonology, Shupik National Medical Academy of Postgraduate Education, Kyiv, Ukraine.

\section{Відомості про авторів:}

Разнатовська О. М., А-р мед. наук, Аоцент, професор каф. фтизіатрії та пульмонології, Запорізький державний медичний університет, Україна.

Бобровнича-Авізова Ю. М., асистент каф. фтизіатрії та пульмонології, Запорізький державний медичний університет, Україна.

Норейко С. Б., А-р меА. наук, Аоцент, професор каф. фтизіатрії та пульмонології, Національний медичний університет імені О. О. Богомольця, м. Київ, Україна.

Гріцова Н. А., канд. меА. наук, доцент каф. фтизіатрії та пульмонології, Національна медична академія післядипломної освіти імені П. ^. Шупика, м. Київ, Україна.

\section{Сведения об авторах:}

Разнатовская Е. Н., А-р меА. наук, Аоцент, профессор каф. фтизиатрии и пульмонологии, Запорожский государственный меАицинский университет, Украина. Бобровничая-Авизова Ю. М., ассистент каф. фтизиатрии и пульмонологии, Запорожский государственный меАицинский университет, Украина.

Норейко С. Б., А-р меА. наук, Аоцент, профессор каф. фтизиатрии и пульмонологии, Национальный меАицинский университет имени А. А. Богомольца, г. Киев, Украина.

Грицова Н. А., канА. меА. наук, Аоцент каф. фтизиатрии и пульмонологии, Национальная медицинская академия последипломного образования имени П. ^. Шупика, г. Киев, Украина.

Конфлікт інтересів: віАсутній.

Conflicts of Interest: authors have no conflict of interest to declare.

НаАійшло Ао редакції / Received: 17.05.2017

Після Аоопрацювання / Revised: 24.05.2017

Прийнято Ао Аруку / Accepted: 01.06.2017 